\title{
Survival of Plant Pathogens in Static Piles of Ground Green Waste
}

\author{
A. J. Downer, D. Crohn, B. Faber, O. Daugovish, J. O. Becker, J. A. Menge, and M. J. Mochizuki
}

First, third, fourth, and seventh authors: University of California Cooperative Extension, 669 County Square Drive, Suite 100, Ventura 93003; second author: University of California, Department of Soils and Environmental Sciences, Riverside 92521; fifth author: University of California, Department of Nematology, Riverside 92521; and sixth author: University of California, Department of Plant Pathology, Riverside 92521.

Accepted for publication 11 December 2007.

\begin{abstract}
Downer, A. J., Crohn, D., Faber, B., Daugovish, O., Becker, J. O., Menge, J. A., and Mochizuki, M. J. 2008. Survival of plant pathogens in static piles of ground green waste. Phytopathology 98:547-554.

Ground green waste is used as mulch in ornamental landscapes and for tree crops such as avocados. Survival of Armillaria mellea, Phytophthora cinnamomi, Sclerotinia sclerotiorum, and Tylenchulus semipenetrans was assessed for 8 weeks within unturned piles of either recently ground or partially composted green waste. S. sclerotiorum survived at the pile surface and at 10,30, and $100 \mathrm{~cm}$ within the pile for the entire 8 weeks in

reducing pathogen viability than $\mathrm{FGW}$, most likely because temperatures in AGW peaked at $45^{\circ} \mathrm{C}$ compared with $70^{\circ} \mathrm{C}$ in FGW. Survival modeling curves based on pile temperatures indicate the time to inactivate 10 propagules of pathogens was $11,30,363$, and 50 days for A. mellea, P. cinnamomi, S. sclerotiorum, and T. semipenetrans, respectively. Sclerotiaforming pathogens pose the greatest risk for escape; to ensure eradication of persistent fungi, green waste stockpiles should be turned intermittently to mix pile contents and move pathogen propagules to a location within the pile where they are more likely to be killed by heat, microbial attack, or chemical degradation.
\end{abstract} both fresh green waste (FGW) and aged green waste (AGW). A. mellea and $T$. semipenetrans did not survive more than 2 days in FGW, while $P$. cinnamomi persisted for over 21 days in FGW. AGW was less effective in
Additional keywords: avocado root rot, citrus nematode, compost, lettuce drop, mulch, oak root rot.
Urban green waste containing tree, shrub, turfgrass, and other landscape plant trimmings or weeds from home gardens and commercial landscapes is used increasingly in California as mulch, most notably in ornamental landscapes and for tree crops such as avocado (9). California generates $1.6 \mathrm{Mg}$ per ha of green waste annually (3), which in addition to being ground to create soil amendments or mulches, may be processed for use as daily landfill cover or combusted for energy recovery.

To minimize costs, green wastes used for agriculture are generally stockpiled without the active management required to support rapid composting. Although decomposition begins as soon as clippings are made, the green waste stream may become contaminated from diseased plants, thus containing inoculum for dissemination. Green wastes also may contain insects and toxic materials such as herbicide residues (26). For large, unturned stockpiles that can often exceed $4.6 \mathrm{~m}$ in height, the center of the pile can become anaerobic, resulting in cooler pile temperatures (23). Pile temperatures can also be affected by seasonal differences in plant content because green waste constituents and properties determine microbial access to energy and nutrients (19).

Plant pathogens may survive on the edges of the pile or just under the surface in cool zones $(7,16)$. For example, Yuen and Raabe (33) found that pathogens survived at the edges of small aerobic compost bins where temperatures did not rise sufficiently. In a study of compost piles that were turned only once, Hoitink et al. (19) found that Phytophthora cinnamomi did not survive a 10 -week incubation process. However, in a noncomposted, sandbased pile, the pathogen could be recovered.

Corresponding author: A. J. Downer; E-mail address: ajdowner@ucdavis.edu

doi:10.1094/PHYTO-98-5-0547

(c) 2008 The American Phytopathological Society
Many authors report studies using turned piles and long sample-retrieval times, but plant pathogen survival in short-term, static stockpiles is not well documented (25). Pathogen escape in sublethal temperature pockets within stockpiles seems likely, especially in unturned piles.

The objectives of this study were (i) to assess fungal, oomycete, and nematode plant pathogen survival over time at various locations in undisturbed stockpiles of either fresh green waste (FGW) or aged green waste (AGW) and (ii) to model the probability of plant pathogen survival according to temperatures measured over time. To accomplish these goals, a logistic regression model assessed the influence of time and location within the pile on pathogen survival. In addition, a probability theory derived and parameterized individual survival functions for each pathogen.

\section{MATERIALS AND METHODS}

Pathogen propagule preparation. Hyphae from Armillaria mellea (Vahl:Fr.) P.Kumm. (oak root rot) were collected in Thousand Oaks, California, from the lower trunk of coast live oaks (Quercus agrifolia) recently diagnosed with active infections. Bark and wood chunks containing $A$. mellea were removed from the infected trees, cut into $30 \times 20 \mathrm{~cm}$ pieces, and placed into nonwoven, permeable bags (Delnet, AET, Middletown, DE). The resulting pieces were similar in size to the chips produced in the green waste grinding operation.

Actively growing P. cinnamomi Rands, isolate M298 (J. Menge, University of California, Riverside) (avocado root rot), was cultured on V8-C broth (100 ml of clarified V8 juice [Campbell Soup Co., Camden, NJ] and $100 \mathrm{ml}$ of $2 \% \mathrm{CaCO}_{3}$ combined with $800 \mathrm{ml}$ of distilled water) in the dark at $24^{\circ} \mathrm{C}$ until the plates were covered with hyphae (about 10 days). Resultant hyphae and accompanying chlamydospores were washed three times with 
deionized water before mycelial mats were separated and placed in $4 \times 4 \mathrm{~cm}, 100 \mu \mathrm{m}$ mesh Miracloth envelopes (Behring Diagnostics, La Jolla, CA) that were sealed with masking tape.

Leaf lettuce plants cultivated in the Oxnard plain growing region of Ventura County, CA, and exhibiting symptoms of lettuce drop were pulled from the ground to include roots and soil at the base of each plant and roots. Sclerotinia sclerotiorum (Lib) de Bary sclerotia were identified, pulled from the base of the plant with forceps, placed in 1:10 dilution of $2.5 \%$ sodium hypochlorite solution for $30 \mathrm{~s}$, and rinsed in sterile distilled water. Sclerotia were blotted dry on paper towels, cut in half with a scalpel, and placed on potato dextrose agar acidified with $1 \mathrm{ml}$ of dilute $(25: 1)$ lactic acid per liter $(25 \%)$ for multiplication. Sclerotia were harvested from plates after 3 weeks and placed in Miracloth bags.

Citrus nematodes (Tylenchulus semipenetrans Cobb) were obtained from an infested orchard at the University of California Riverside, Agriculture Experimentation Station. Feeder roots heavily parasitized by $T$. semipenetrans were excavated and excess soil was carefully removed by washing. The roots were cut into $10-\mathrm{mm}$ pieces and mixed into pasteurized sandy soil. Small muslin bags (Hubco Soil Sample Bags, Forestry Supplies, Inc., Jackson, MS) were filled with $5 \times 10^{-3} \mathrm{~cm}^{3}$ of the infested soil and roots.

Pile formation, pathogen placement, and recovery. After placement in their respective containment bags or envelopes, all of the pathogen propagules were placed together in larger Delnet bags. To ensure green waste contact with pathogens, the bags were partially filled with the same material comprising the piles. These bags were then tied closed with polypropylene construction string.

Chipped yard waste was collected within $2 \mathrm{~h}$ of grinding. Municipal yard waste materials primarily consisted of prunings of landscape trees and turfgrass clippings in an approximate ratio of 80:20 (percent by volume) from the Oxnard, CA area. Materials were further ground with a horizontal hog grinder (Morbark Inc., Winn, MN) without a screen to produce pieces 2 to $6 \mathrm{~cm}$ in length. Ground green waste was piled in a $4 \mathrm{~m}^{3}$ circle, $1 \mathrm{~m}$ high on concrete slabs. Pathogen bags were placed into the pile at 0 (pile edge), 15, 30, and $100 \mathrm{~cm}$ inward toward the pile center such that nine rows of bags were arranged in a spoke-like pattern over the circular pile. Bags were covered with an additional $4 \mathrm{~m}^{3}$ of green waste, creating a 2-m-high pile. Five replicate piles were built for each experiment. Temperature data loggers (Watch Dog Model 100, Spectrum Technologies, Plainfield, IL) were included with the last set of bags.

Bags were removed at $0.5,1,2,4,7,14,21,28$, and 56 days after pile establishment. Each trial was therefore designed as a randomized complete block factorial experiment with location and time in the pile as factors. At each sampling time and location, temperatures were also recorded with a hand-held thermocouple (Digi-Sense, 8528-20, Cole Parmer, Niles, IL).

For the last three experiments, additional sets of five piles in each experiment were constructed with 18-month-old aged yard waste. Piles were prepared and pathogens were placed in piles as described above.

Experiments using FGW (fresh trial [FT] 1, 2, 3, 4, and 5) were initiated on 5 September 2001; 18 April, 17 July, and 5 December 2002; and 2 April 2003, respectively. Experiments using AGW (aged trial [AT] 1, 2, and 3) were established on 17 July and 5 December 2002, and 2 April 2003, the same dates as FT 3, 4, and 5 . Ambient low and high temperatures in Oxnard were 15 and $30^{\circ} \mathrm{C}$, respectively.

Samples of green waste from each 8-week experiment were collected for nitrogen, carbon and organic matter content, $\mathrm{pH}$, and salinity (electrical conductivity) analysis by the Division of Agriculture and Natural Resources Analytical Laboratory, University of California, Davis. Water content was determined by weight loss after oven drying.
Sample isolations and identification. Bark chunks infected with $A$. mellea were removed from their bags, washed with water, and placed in 1:10 dilution of $2.5 \%$ sodium hypochlorite for $10 \mathrm{~min}$. The bark was rinsed in $500 \mathrm{ml}$ of sterile distilled water before dissecting with forceps to reveal unexposed A. mellea hyphae. Hyphae were plated on differential potato dextrose agar ( $20 \mathrm{~g}$ of potato dextrose agar, benomyl at $10 \mu \mathrm{g} / \mathrm{ml}$, and $1 \mathrm{ml}$ of dilute [25\%] lactic acid per liter) and plates were incubated at room temperature ranging from 22 to $24^{\circ} \mathrm{C}$ and ambient light for up to 4 weeks. Identifications were declared positive if hyphae and rhizomorphs typical of A. mellea were observed growing into the medium. All viable isolations of A. mellea readily formed rhizomorphs in culture. Fungal inhabitants (mainly Trichoderma viride) isolated from A. mellea inoculum were also recorded.

Hyphae of $P$. cinnamomi were washed with running water, removed from the envelopes, and plated directly on pimaricin, ampicillin, rifampicin, PCNB, and hymexasol (PARPH) media (21). Plates were incubated at $24^{\circ} \mathrm{C}$ for 3 days and positive identifications were made by observation of the colony morphology typical of $P$. cinnamomi.

Sclerotia of $S$. sclerotiorum were removed from the envelopes and placed in 1:10 dilution of $2.5 \%$ sodium hypochlorite solution for $30 \mathrm{~s}$ and rinsed in sterile distilled water. Sclerotia were blotted dry on paper towels, cut in half with a scalpel, and placed on acidified potato dextrose agar. Positive identification was made when colonies reformed sclerotia typical of $S$. sclerotiorum after 1 week.

Nematode assays were done following the protocol of Becker et al. (1). The contents of each buried bag were individually incubated on a Baermann funnel at $26^{\circ} \mathrm{C}$ for 5 days. The collected nematodes were identified and enumerated with the aid of a dissecting microscope at $\times 40$ magnification.

Samples collected from replicate piles and pile positions were assigned values of 1 (live) and 0 (dead) based on respective culture or assay results.

Statistical analyses. Mineral and water content of ground green waste were analyzed with a $t$ test (unpaired data) for FGW trials compared with aged trials using the two sample $t$ test procedure in Minitab (Minitab Inc., State College, PA).

The survival of pathogens as a function of time and location within the piles was evaluated using regression models. Because pathogen survival was a binary response (dead or alive), probability of survival was assessed using a binary logistic regression model based on equation 1 (nomenclature listed in Table 1)

$$
P=\frac{1}{1+e^{-\left(B 0+B_{1} t+B_{2} y\right)}}
$$

where $P$ is the probability of pathogen survival, $B_{0}$ is an intercept parameter, and $B_{1}$ and $B_{2}$ are coefficients for the effects of burial time in days $(t)$ and burial depth in centimeters $(y)$, respectively. Significance of the parameters of equation 1 was evaluated using the logistic procedure in SAS (version 9, SAS Institute, Cary, NC). The Hosmer-Lemeshow lack-of-fit test (22) was used to examine the degree to which the logistic regression model fit the data. In cases where the Hosmer-Lemeshow lack-of-fit test statistic was significant $(P<0.05)$, indicating lack of fit of the logistic regression model, percent survival data were log-transformed and analyzed using the general linear model procedure. No violation of the assumptions of equal variance and normal distribution was detected. Individual models were fitted for each pathogen within each trial because experiment was found to be a significant factor when data for all trials were analyzed collectively. Burial time and burial depth did not interact and are presented separately.

Survival functions. For each pathogen, the data from the different experiments were used collectively to parameterize survival functions representing the probability of its survival over time 
under changing temperature conditions. The probability that a given pathogen sample remains viable at time $t$ can be represented as a first-order process. Standard first-order survival is expressed as

$$
p_{t}=e^{-k t}
$$

where $t$ is time in days and $k$ is an inactivation rate constant $\left(\mathrm{d}^{-1}\right)$ (Table 1). However, survival kinetics strongly depend on temperature. To apply this equation under varying temperature conditions, the following integrals must be solved:

$$
p_{t}=e^{-\int_{0}^{t} k(T(\hat{t})) d \hat{t}}
$$

where survival constant $k$ is a function of temperature, $T(\mathrm{~K})$, which is in turn a function of time, $\hat{t}$ (days) (Table 1) $(4,6)$. Soilborne pathogen survival has been shown to be consistent with the Arrhenius equation (29), which can be written as

$$
k_{T}=k_{r} Q_{10}{ }^{\left(1+T_{r} / 10\right)\left(1-T_{r} / T\right)}
$$

where $k_{T}\left(\mathrm{~d}^{-1}\right)$ is the decay rate at temperature $T(\mathrm{~K}), k_{r}\left(\mathrm{~d}^{-1}\right)$ is the decay rate at reference temperature $T_{r}(\mathrm{~K})$, and $Q_{10}$ is the relative proportion by which $k_{r}$ increases after a $10^{\circ} \mathrm{C}$ temperature increase from the reference temperature $\left(Q_{10}=k_{T_{r}+10} / k_{T_{r}}\right)$ (Table 1) $(4,6)$. When the Arrhenius equation is substituted into equation 3, the survival rates can be brought outside of the integrals. A numerical solution can then be written in terms of temperatureadjusted time (TAT), $t^{\circ}$ (days), by summing the TAT associated with previous time intervals.

$$
p_{t^{\circ}}=e^{-k t^{\circ}}
$$

and

$$
t^{\circ}=\sum_{\forall i \ni \hat{t}_{i}<t} Q_{10}\left(1+\frac{T_{r}}{10}\right)\left(1-\frac{T_{r}}{T\left(\hat{t}_{i}\right)}\right)\left(\hat{t}_{i+1}-\hat{t}_{i}\right)
$$

where $\hat{t}_{i}$ values are consecutive temperature measurement times and an exact solution is found as $i \rightarrow \infty$. Rate $k$ has units of $\mathrm{d}^{\circ-1}$ and is constant across all temperatures (Table 1).

Each pathogen was assumed to have probability $p_{t^{\circ}}$ of being infectious at TAT $t^{\circ}$. Each sampling event, $j$, contained $r=5$ replications so that the number of viable replications, $i_{j}$, could range from 0 to 5 . The number of positive bags collected in a particular event can therefore be represented as a binomial event, with a probability density function of

$$
f_{B}\left(i_{j} \mid p_{t^{\circ}}, r\right)=\left(\begin{array}{l}
r \\
i_{j}
\end{array}\right) p_{t^{\circ}} i_{j}\left(1-p_{t^{\circ}}\right)^{r-i_{j}}
$$

Parameterization. Data for temperature, $T$, and the number of viable replicates, $i_{j}$, were collected for each sampling event, $j$. Parameters $k$ and $Q_{10}$ were then estimated using all of the sampled data by applying maximum log-likelihood estimation (20) and solving the following formula with the Solver tool included with Microsoft Excel

$$
\operatorname{Max} \sum_{\forall j} \ln \left[f_{B}\left(i_{j} \mid k, Q_{10}\right)\right]
$$

Goodness-of-fit test. A goodness-of-fit test was derived by using a Bonferroni inequality to test the fit from multiple collection events simultaneously. The test constructs a one-sided multinomial confidence interval $(5,10)$ such that the probability that all included sampling events fall within it is $1-\alpha$. Location of one or more data points located outside of the confidence interval results in the rejection of the model.
To maximize the number of sampling dates included in the test, the procedure was structured so that rejection would occur if all five replicates $(r=5)$ from a given date were positive $\left(i_{j}=r\right)$. A subset of the experiments must be used to construct the confidence interval because of the high probability associated with $i_{j}=$ $r$ when TAT is low. In other words, because early in the experiment the probability is high that all replicates will be positive, those sampling events were not tested. The size of the set of events that were included in the test was maximized by finding the sampling event $\hat{j}$ such that inclusion of all experiments, $j$, with lesser survival probabilities results in a confidence interval just bounded by $\alpha=0.05$

$$
\begin{aligned}
& \operatorname{Min}_{\hat{j}} \text { s.t. } \\
& \alpha_{\hat{j}} \geq \alpha \\
& \alpha_{\hat{j}}=\prod_{p_{j} \leq p_{\hat{j}}}\left(1-p_{j}^{r}\right)
\end{aligned}
$$

Thus, we ordered all of the observed outcomes, regardless of their trial of origin, by their observed probabilities. Events were then considered in increasing order of probability, $p_{j}$, until the predetermined $\alpha$ level of 0.05 was reached. If, for any of the selected sampling events, all replicates for a given pathogen were positive $\left(i_{j}=r=5\right)$, the model was rejected. This approach has the advantage in that it considers the maximum number of sampling dates in the data set. (Inclusion of data from the first day or two might result in a test dependent on just one observation.) It also emphasizes the tail of the data set (later data) over observations

\begin{tabular}{|c|c|}
\hline Symbol & Definition \\
\hline$\alpha$ & Goodness-of-fit test rejection criterion \\
\hline$B_{0}$ & Intercept parameter in binary logistic regression model \\
\hline$B_{1}$ & $\begin{array}{l}\text { Coefficient for the variable associated with burial time in days } \\
(x) \text { in binary logistic regression model }\end{array}$ \\
\hline$B_{2}$ & $\begin{array}{l}\text { Coefficient for the variable associated burial time in days }(y) \text { in } \\
\text { binary logistic regression model }\end{array}$ \\
\hline $\mathrm{d}$ & Days \\
\hline$d^{\circ}$ & Unit representing temperature-adjusted days \\
\hline$f_{B}$ & Probability that $i$ of $r$ bags contain viable pathogens at TAT $t^{\circ}$ \\
\hline$i$ & Number of bags found to be positive for a pathogen of interest \\
\hline$j$ & Index indicating a particular sampling event \\
\hline$k$ & Pathogen inactivation rate $\left(\mathrm{d}^{-1}\right.$ or $\left.\mathrm{d}^{\mathrm{o-1}}\right)$ \\
\hline$k_{r}$ & Pathogen inactivation rate at the reference temperature, $T_{r}\left(\mathrm{~d}^{-1}\right)$ \\
\hline$k_{T}$ & Temperature-adjusted inactivation rate $\left(\mathrm{d}^{-1}\right)$ \\
\hline$P$ & $\begin{array}{l}\text { Probability of pathogen survival using binary logistic regression } \\
\text { model }\end{array}$ \\
\hline$p_{t}$ & Probability that an infectious pathogen survives until time $t$ \\
\hline$P_{t^{\circ}}$ & $\begin{array}{l}\text { Probability that a infectious pathogen survives until } \\
\text { temperature-adjusted time } t^{\circ}\end{array}$ \\
\hline$Q_{10}$ & $\begin{array}{l}\text { Fractional change in the inactivation rate after a } 10^{\circ} \mathrm{C} \text { increase } \\
\text { in temperature from the reference temperature, } T_{r}\end{array}$ \\
\hline$r$ & Number of inserted bag replications \\
\hline & Time (days) \\
\hline$T^{\circ}$ & Temperature-adjusted time or TAT $\left(\mathrm{d}^{\circ}\right)$ \\
\hline$T(t)$ & Absolute temperature at time $t(\mathrm{~K})$ \\
\hline$T_{r}$ & Arrhenius equation reference temperature $(\mathrm{K})$ \\
\hline TAT & Temperature-adjusted time \\
\hline$w$ & $\begin{array}{l}\text { Probability that no infectious pathogens survive at a given } \\
\text { temperature-adjusted time }\end{array}$ \\
\hline
\end{tabular}
occurring in the first 2 or 3 days after insertion. It is most important to represent the later data well because the green waste applied as mulch by growers is likely to be older than 2 to 3 days.

Inactivation model. The probability that all pathogens are eliminated from the pile with probability $w$ can be determined by estimating the total number of pathogens in the pile, $j$, and applying equations 5 and 7 , where $i_{j}=0$

TABLE 1. Nomenclature for analytical models 


$$
w=\left(1-e^{-k t^{\circ}}\right)^{r}
$$

The TAT, $t^{\circ}$, required to accomplish this is

$$
t^{\circ}=-\frac{1}{k} \ln (1-\sqrt[r]{w})
$$

If the temperature, $T(\mathrm{~K})$, is fixed, the amount of unadjusted time, $t$ (days), required to eliminate the pathogens can be determined as

$$
t=-\frac{\ln \left(1-w^{1 / r}\right)}{k} Q_{10}^{\left(1+\frac{T_{r}}{10}\right)\left(\frac{T_{r}}{T}-1\right)}
$$

\section{RESULTS}

Chemical and physical properties of green waste piles. Chemical properties of FGW and AGW were similar at the time of pile construction $(P>0.05$; Table 2$)$. Although water content of FGW was significantly higher than that of AGW $(P<0.001$; Table 2), both contained sufficient moisture levels to promote biological degradation of pathogens.

Pile temperatures generally increased with depth in both FGW and AGW piles (Fig. 1). Temperatures were similar between the two types of green waste at the surface but at 15,30 , and $100 \mathrm{~cm}$ depths, pile temperatures in FGW ranged from 30 to $35 \%$ higher than in AGW (Fig. 1A). During the 56 day trial, FGW pile temperatures decreased while AGW remained relatively stable (Fig. 1B).

Effect of burial time and burial depth on pathogen survival. Burial time affected $P$. cinnamomi survival in three of the seven trials, particularly in AT 1 and AT $3(P<0.05$; Table 3$)$. $P$. cinnamomi did not survive past 4 to 6 days in FT 2 and AT 3, respectively, but persisted past 28 days in AT 1 . After 56 days, no $P$. cinnamomi remained alive in any of the FGW or AGW piles. Burial depth was significant in two trials where time was not significant $(P<0.05$; Table 3$)$. In FT 1 and $4, P$. cinnamomi survived better at the surface of both the FGW and AGW piles than at interior locations.
Burial time affected A. mellea survival in three of five trials. This pathogen did not survive after 1 week in either FGW or AGW piles; in FT $1, A$. mellea was inactivated after 1 day $(P<0.001$; Table 4). Burial location was a significant factor affecting survival only in FT $2(P<0.01$; Table 4$)$, in which A. mellea was only recovered at the pile edge. The logistic regression model appeared to fit $A$. mellea survival best compared with the other pathogens; no data transformation was required for any $A$. mellea experiments.

Survival of $S$. sclerotiorum was affected by burial time in two of five trials, including one fresh trial and one aged trial $(P<$ 0.001; Table 5). In FT 2, sclerotia were not viable after 21 days; in AT 3, survival generally decreased at each sampling date but $45 \%$ of sclerotia were still viable after 56 days. Burial depth affected $S$. sclerotiorum survival in all trials $(P<0.05$; Table 5), with sclerotia survival generally decreasing inward from $30 \mathrm{~cm}$ into the pile. However, some viable sclerotia were recovered in all trials $1 \mathrm{~m}$ into the pile. In AT 2, for example, more than $50 \%$ of the sclerotia recovered from the pile center were viable $(P<0.01$; Table 5).

Burial time was an important factor affecting nematode survival in two of five trials, in which they did not survive past 4 days $(P<$ 0.01 ; Table 6 ). After 8 weeks, none of the samples from any of the piles contained living $T$. semipenetrans, while nematodes in concomitant laboratory storage at room temperatures ranging from 22 to $24^{\circ} \mathrm{C}$ survived the entire 8 weeks (data not shown). Burial location was significant only in FT 1, in which $33 \%$ of nematodes survived on the surface compared with $4 \%$ at the $1 \mathrm{~m}$ depth $(P<$ 0.05; Table 6).

Survival functions. Goodness-of-fit was acceptable $(\alpha \geq 0.05)$ for A. mellea, $T$. semipenetrans, and $S$. sclerotiorum, indicating that pile temperature related to survival of all pathogens evaluated except $P$. cinnamomi. The estimated $Q_{10}$ values, indicating the rate of increase of organism decay with a corresponding $10^{\circ} \mathrm{C}$ increase in pile temperature, ranged from 1.38 for A. mellea to 2.58 for $S$. sclerotiorum with the relative order A. mellea $<P$. cinnamomi $<$ $T$. semipenetrans $<S$. sclerotiorum (Table 7). The estimated inactivation rates, $k$, ranged from $0.0145 \mathrm{~S}$. sclerotiorum sclerotia per day to 0.492 A. mellea hyphae per day. The magnitudes of $Q_{10}$ and $k$ were inversely correlated.

TABLE 2. $\mathrm{pH}$, electrical conductivity (EC), ammonium-nitrogen $\left(\mathrm{NH}_{4}\right)$ content, nitrate-nitrogen content $\left(\mathrm{NO}_{3}\right)$, total nitrogen content ( $\left.\mathrm{N}_{\text {tot }}\right)$, total carbon content $\left(\mathrm{C}_{\text {tot }}\right)$, water content $\left(\mathrm{H}_{2} \mathrm{O}\right)$, and organic matter content $(\mathrm{OM})$ of fresh (recently chipped) and aged (18-month-old) green wastes near Oxnard, $\mathrm{CA}$

\begin{tabular}{lcccccccc}
\hline Green waste & $\mathrm{pH}$ & $\mathrm{EC}\left(\mathrm{dS} \cdot \mathrm{m}^{-1}\right)^{\mathrm{y}}$ & $\mathrm{NH}_{4}\left(\mu \mathrm{g} \cdot \mathrm{g}^{-1}\right)$ & $\mathrm{NO}_{3}\left(\mu \mathrm{g} \cdot \mathrm{ml}^{-1}\right)$ & $\mathrm{N}_{\text {tot }}(\%)$ & $\mathrm{C}_{\text {tot }}(\%)$ & $\mathrm{H}_{2} 0(\%)$ & $\mathrm{OM}(\%)$ \\
\hline Fresh & 6.7 & 12.3 & 46.7 & 655 & 1.47 & 30.8 & $40.0 \mathrm{a}^{\mathrm{z}}$ & 60.1 \\
Aged & 6.6 & 10.4 & 76.7 & 407 & 1.46 & 30.0 & $34.9 \mathrm{~b}$ & 60.4 \\
\hline
\end{tabular}

${ }^{\mathrm{y}}$ DeciSiemens per meter.

${ }^{\mathrm{z}}$ Water content was significantly different $(P=0.0009)$ according to unpaired $t$ test.
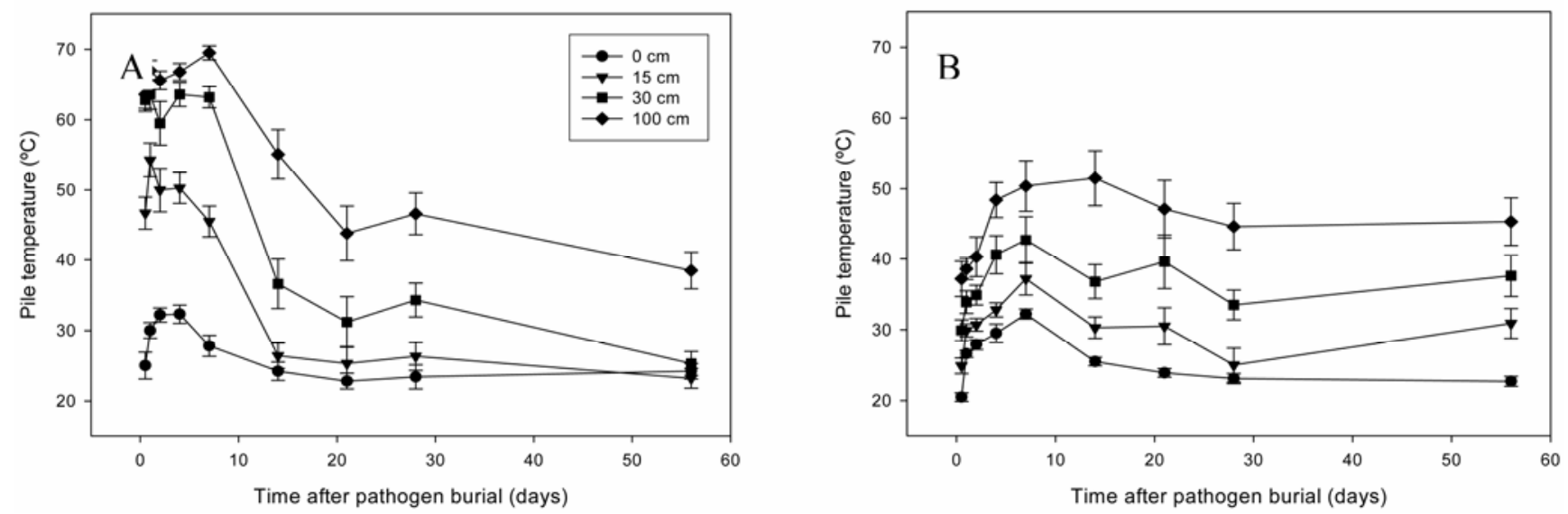

Fig. 1. Mean pile temperature and standard error over time at four depths within A, fresh (recently chipped) and B, aged (18-month-old) green wastes near Oxnard, CA. 
The survival models developed here apply whether temperatures vary or not. The time to completely eliminate 1,000 pathogen propagules with $99 \%$ certainty with a constant pile temperature of $30^{\circ} \mathrm{C}$ is 20 days for A. mellea (Fig. 2A), 54 days for $P$. cinnamomi (Fig. 2B), 80 days for T. penetrans (Fig. 2C), and 500 days for S. sclerotiorum (Fig. 2D). (The P. cinnamomi results are included for comparison purposes only.) Times to elimination at constant temperatures are comparable among species.

The time required for elimination of $100 \%$ pathogen propagules with $99 \%$ certainty, adjusting for the temperature variability measured in the pile, was 23 days for A. mellea (Fig. 2A legend), 65 days for P. cinnamomi (Fig. 2B legend), 109 days for T. penetrans (Fig. 2C legend), and 793 days for S. sclerotiorum (Fig. 2D legend). The temperature-adjusted times for pathogen elimination are not directly comparable among species due to differences in $Q_{10}$ values.

\section{DISCUSSION}

In many pathogen/composting studies, the exposure of pathogens in plant tissues to heat accounts for their death in the composting process. Bollen et al. (2) found that static piles undergo a heat phase for a period of 2 to 3 weeks that was mainly responsible for pathogen kill. Later, during the curing phase of composting, antagonism between fungal pathogens and compost microbes may result in further pathogen control $(2,18)$. In this inoculation study, the interior areas of unturned FGW piles heated to lethal temperatures for 2 to 3 weeks, but piles made from unturned AGW remained low, warming slowly from the pile center.

The relatively modest $Q_{10}$ values for $A$. mellea combined with a high $k$ value indicate that this organism has difficulty persisting in the compost piles, even at ambient temperatures. We would expect the $Q_{10}$ value to be higher if measured under controlled conditions in which only temperature is varied. Such a result would also likely lower the rate of inactivation fitted with this model.

A. mellea and $P$. cinnamomi display similar sensitivities to heat (Table 7), but $A$. mellea is less hardy, with an inactivation rate of 0.492 propagules per day versus 0.177 propagules per day for P. cinnamomi (Fig. 2B and D). A. mellea in all FGW piles as well as in AT 3 was greatly reduced within 1 to 2 days after insertion.
In the other AGW trial, A. mellea persisted only through day 4. The relatively brief survival of $A$. mellea in our study suggests that factors besides heat contributed to its death. Possible factors include drying $(24,27)$, increased ammonia level $(14,28)$, inhibitors from barks (17), and competition with other mulch organisms, such as Trichoderma spp. which can kill A. mellea (24). We observed an increase in the isolation of Trichoderma viride from recovered $A$. mellea over the course of incubations in both fresh piles and aged piles (data not shown). The increase was observed with concomitant disappearance of recoverable live $A$. mellea from samples. It is likely that Trichoderma spp. play a role in control of $A$. mellea that has been partially destroyed or stressed by heating in the compost pile.

TABLE 4. Percent survival of Armillaria mellea (causing oak root rot) recovered from fresh (recently chipped) and aged (18-month-old) green waste at nine sampling dates and at four depths (distance from edge of yard waste pile toward the center) near Oxnard, CA

\begin{tabular}{|c|c|c|c|c|c|}
\hline & \multicolumn{5}{|c|}{ Survival $(\%)^{\mathrm{y}}$} \\
\hline & \multicolumn{3}{|c|}{ Fresh trial number } & \multicolumn{2}{|c|}{ Aged trial numbe } \\
\hline & 1 & 4 & 5 & 1 & 3 \\
\hline \multicolumn{6}{|c|}{ Time (days) } \\
\hline 0.5 & 45 & 30 & 5 & 50 & 5 \\
\hline 1 & 15 & 10 & 15 & 35 & 10 \\
\hline 2 & 0 & 10 & 0 & 25 & 10 \\
\hline 4 & 0 & 5 & 0 & 25 & 5 \\
\hline 7 & 0 & 5 & 0 & 0 & 0 \\
\hline 14 & 0 & 0 & 0 & 0 & 0 \\
\hline 21 & 0 & 0 & 0 & 0 & 0 \\
\hline 28 & 0 & 0 & 0 & 0 & 0 \\
\hline 56 & 0 & 0 & 0 & 0 & 0 \\
\hline$P$ value & 0.0095 & 0.0114 & $\mathrm{NS}^{\mathrm{z}}$ & 0.0010 & NS \\
\hline \multicolumn{6}{|c|}{ Depth $(\mathrm{cm})$} \\
\hline 0 & 9 & 29 & 6 & 18 & 7 \\
\hline 15 & 6 & 2 & 0 & 11 & 4 \\
\hline 30 & 4 & 0 & 0 & 16 & 2 \\
\hline 100 & 6 & 0 & 2 & 16 & 0 \\
\hline$P$ value & NS & 0.0008 & NS & NS & NS \\
\hline
\end{tabular}

TABLE 3. Percent survival of Phythopthora cinnamomi (causing avocado root rot) mycelia recovered from fresh (recently chipped) and aged (18-month-old) green waste at nine sampling dates and at four depths (distance from edge of yard waste pile toward the center) near Oxnard, CA

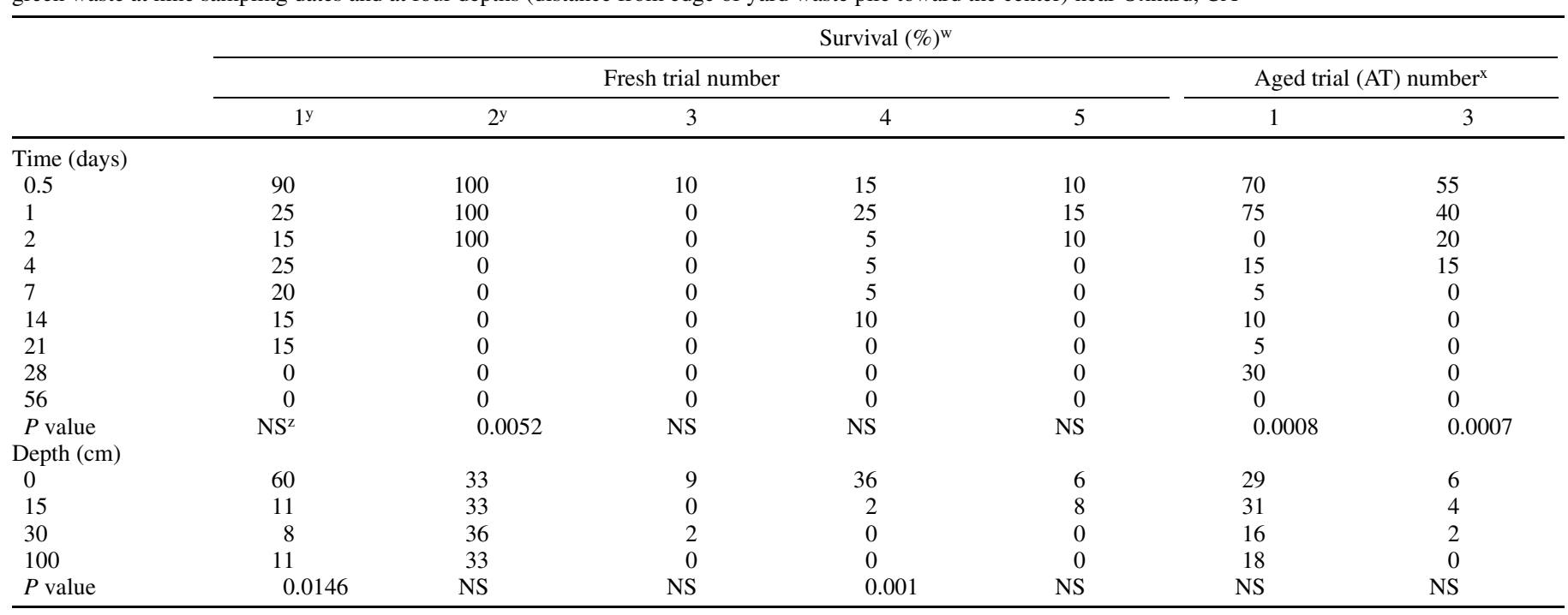

w Time and depth did not interact $(P>0.05)$. Each percentage is a mean of five replications.

${ }^{x}$ There was no P. cinnamomi survival in AT 2 .

${ }^{y}$ Binary logistic regression model did not fit the data (Hosmer-Lemeshow lack of fit, $P<0.05$ ); instead, percent survival was log-transformed and analyzed using an analysis of variance model with no violation of assumptions detected.

${ }^{z}$ NS is not significant at $P<0.05$. 
Erwin and Ribeiro (12) stated that $P$. cinnamomi will not persist above $45^{\circ} \mathrm{C}$ for more than a few hours. In this study, we found that $P$. cinnamomi survived up to 1 week in fresh piles that reached temperatures above $60^{\circ} \mathrm{C}$. During FT 2, P. cinnamomi persisted strongly for 3 days after insertion into the piles. After the third day, however, the pattern of complete survival changed to one of almost complete elimination. From the fifth day forward, no viable $P$. cinnamomi were observed during FT 2, except for a single survivor at $30 \mathrm{~cm}$ on day 8 . It is not clear why $P$. cinnamomi survived and then abruptly perished in FT 2 but because of this sudden change, the $P$. cinnamomi model was not accepted by the goodness-of-fit test. Additional research is warranted to appropriately parameterize the inactivation of $P$. cinnamomi.

Composts made from barks of hardwood trees contain inhibitors that affect the survival of Phytophthora spp. (18). The green wastes used in our experiments always contained large quantities of landscape trees and their barks, including Eucalyptus spp., a common landscape tree in California. Downer et al. (8) found that enzyme systems in woody mulches composed of Eucalyptus globulus create a soil environment destructive to $P$. cinnamomi. Ammonia is also toxic to $P$. cinnamomi (30). The low $Q_{10}$ and $k$ values associated with $P$. cinnamomi suggest a maximum survival time of 54 days, assuming 1,000 infectious units and minimum pile temperatures of $30^{\circ} \mathrm{C}$. The combination of high temperatures, possible bark-related inhibitors, cellulytic enzymes, and antagonistic fungi in FGW appears to create an environment that is most adverse for $P$. cinnamomi.

$S$. sclerotiorum was the most persistent plant pathogen in this study. The high $Q_{10}$ value (2.58) and low $k$ value $\left(0.0145\right.$ day $\left.^{-1}\right)$ for $S$. sclerotiorum predict survival at ambient temperatures but susceptibility to heat. Although temperatures in fresh piles remained above $45^{\circ} \mathrm{C}$ for over 2 weeks, sclerotia survived at 0,15 , and $100 \mathrm{~cm}$ depth in FGW piles and in all zones in AGW piles after 56 days. S. sclerotiorum populations at the centers of the FGW piles were greatly reduced but not eliminated; our model

TABLE 5. Percent survival of Sclerotinia sclerotiorum (causing lettuce drop) sclerotia recovered from fresh (recently chipped) and aged (18-month-old) green waste at nine sampling dates and at four depths (distance from edge of yard waste pile toward the center) near Oxnard, CA

\begin{tabular}{|c|c|c|c|c|c|}
\hline & \multicolumn{5}{|c|}{ Survival $(\%)^{\mathrm{x}}$} \\
\hline & \multicolumn{3}{|c|}{ Fresh trial number } & \multicolumn{2}{|c|}{ Aged trial number } \\
\hline & 2 & $3^{y}$ & $5^{y}$ & 2 & 3 \\
\hline \multicolumn{6}{|c|}{ Time (days) } \\
\hline 0.5 & 56 & 25 & 25 & 85 & 85 \\
\hline 1 & 40 & 25 & 50 & $\mathrm{NA}^{\mathrm{z}}$ & 95 \\
\hline 2 & 35 & 15 & 45 & 70 & 50 \\
\hline 4 & 10 & 20 & 20 & 45 & 65 \\
\hline 7 & 20 & 20 & 45 & 70 & 80 \\
\hline 14 & 35 & 35 & 25 & 55 & 55 \\
\hline 21 & 15 & 10 & 35 & 90 & 50 \\
\hline 28 & 0 & 10 & 40 & 75 & 35 \\
\hline 56 & 0 & 10 & 35 & 40 & 45 \\
\hline$P$ value & 0.0003 & $\mathrm{NS}^{\mathrm{z}}$ & NS & NS & 0.0001 \\
\hline \multicolumn{6}{|c|}{ Depth (cm) } \\
\hline 0 & 49 & 58 & 87 & 78 & 100 \\
\hline 15 & 20 & 9 & 44 & 78 & 73 \\
\hline 30 & 11 & 2 & 8 & 58 & 51 \\
\hline 100 & 13 & 6 & 2 & 53 & 24 \\
\hline$P$ value & 0.0034 & 0.0407 & 0.0427 & 0.0108 & 0.0001 \\
\hline
\end{tabular}

${ }^{\mathrm{x}}$ Time and depth did not interact $(P>0.05)$. Each percentage is a mean of five replications.

${ }^{y}$ Binary logistic regression model did not fit the data (Hosmer-Lemeshow lack of fit, $P<0.05$ ); instead, percent survival was log-transformed and analyzed using an analysis of variance model with no violation of assumptions detected.

${ }^{\mathrm{z}} \mathrm{NS}$ is not significant at $P<0.05$; NA is not available (samples were not recovered). suggests that $S$. sclerotiorum populations will be reduced significantly after more than 1 year in the pile. Dittmer et al. (7) found that $S$. sclerotiorum survived 14 days at temperatures exceeding $70^{\circ} \mathrm{C}$ and for 20 days in piles that reached $44^{\circ} \mathrm{C}$ at their center, but other studies have documented S. sclerotiorum and other sclerotia-forming pathogens to be deactivated by compost pile heating or aerated steam heating in soil $(2,19,31,33)$.

Unlike the fungi and $P$. cinnamomi, nematodes inserted into the pile contained dozens to hundreds of individuals. Although surviving nematodes might be modeled differently, for consistency we chose to examine them as binary occurrences representing the incomplete/complete inactivation of all nematodes in each sample. Nematodes were heat sensitive $\left(Q_{10}=1.83\right)$ and were largely inactivated within a few days to 1 week of insertion, except at the pile surface where they persisted for several weeks.

Hoitink and Fahy (18) assert that nematode phytopathogens are very susceptible to increased temperatures experienced in compost piles. Temperature sensitivity likely varies based on nematode species or populations in addition to physiological and environmental conditions. However, several studies suggested that exposure to a constant temperature above $46^{\circ} \mathrm{C}$ for several hours should eliminate most plant-parasitic nematodes $(11,13,15,32)$. Furthermore, daily exposure of nematode-infested soil to lethal

TABLE 6. Percent survival of Tylenchulus semipenetrans (citrus nematode) recovered from fresh (recently chipped) and aged (18-month-old) green waste at nine sampling dates and at four depths (distance from edge of yard waste pile toward the center) near Oxnard, CA

\begin{tabular}{|c|c|c|c|c|c|}
\hline & \multicolumn{5}{|c|}{ Survival $(\%)^{\mathrm{y}}$} \\
\hline & \multicolumn{4}{|c|}{ Fresh trial number } & \multirow{2}{*}{$\frac{\text { Aged trial number }}{1^{\mathrm{z}}}$} \\
\hline & $1^{\mathrm{z}}$ & 2 & 3 & $4^{\mathrm{z}}$ & \\
\hline \multicolumn{6}{|c|}{ Time (days) } \\
\hline 0.5 & 50 & 45 & 85 & 50 & 100 \\
\hline 1 & 45 & 10 & 20 & 30 & 100 \\
\hline 2 & 35 & 0 & 10 & 50 & 70 \\
\hline 4 & 0 & 0 & 0 & 20 & 45 \\
\hline 7 & 0 & 0 & 0 & 10 & 5 \\
\hline 14 & 15 & 0 & 0 & 10 & 0 \\
\hline 21 & 0 & 0 & 0 & 10 & 10 \\
\hline 28 & 0 & 0 & 0 & 15 & 30 \\
\hline 56 & 0 & 0 & 0 & 0 & 0 \\
\hline$P$ value & NS & 0.0094 & 0.0004 & NS & NS \\
\hline \multicolumn{6}{|c|}{ Depth $(\mathrm{cm})$} \\
\hline 0 & 33 & 8 & 18 & 60 & 40 \\
\hline 15 & 20 & 8 & 8 & 4 & 49 \\
\hline 30 & 6 & 4 & 11 & 2 & 33 \\
\hline 100 & 4 & 2 & 13 & 6 & 38 \\
\hline$P$ value & 0.0437 & $\mathrm{NS}$ & NS & NS & NS \\
\hline
\end{tabular}

y Time and depth did not interact $(P>0.05)$. Each percentage is a mean of five replications.

${ }^{\mathrm{z}}$ Binary logistic regression model did not fit the data (Hosmer-Lemeshow lack of fit, $P>0.05$ ); instead, percent survival data were log-transformed and analyzed using an analysis of variance model with no violation of assumptions detected.

TABLE 7. Estimated parameter values for inactivation of Armillaria mellea (oak root rot), Phytophthora cinnamomi (avocado root rot), Sclerotinia sclerotiorum (lettuce drop) and Tylenchulus semipenetrans (citrus nematode) after burial in fresh (recently chipped) and aged (18-month-old) green waste near Oxnard, $\mathrm{CA}^{\mathrm{z}}$

\begin{tabular}{lcccc}
\hline & P. cinnamomi & A. mellea & S. sclerotiorum & T. semipenetrans \\
\hline$Q_{10}$ & 1.45 & 1.38 & 2.58 & 1.83 \\
$k$ & 0.177 & 0.492 & 0.0145 & 0.106 \\
\hline
\end{tabular}

${ }^{\mathrm{z}}$ Estimated $Q_{10}$ values indicate the rate of increase in pathogen decay with a corresponding $10^{\circ} \mathrm{C}$ increase in pile temperature. Estimated $k$ values indicate the rate of inactivation (number of propagules per day). Goodness-of-fit was acceptable $(\alpha \geq 0.05)$ for $A$. mellea, $T$. semipenetrans, and $S$. sclerotiorum, indicating that pile temperature related to survival of all pathogens evaluated except $P$. cinnamomi, which is included for comparison. 
temperatures for sublethal time periods may have a cumulative lethal effect (15).

The intermediate $Q_{10}$ value and survival time of 54 days (assuming 1,000 infectious units and minimum pile temperatures of $30^{\circ} \mathrm{C}$ ) for citrus nematode suggest a greater chance of survival than for $P$. cinnamomi or A. mellea in the same pile systems; however, spurious surviving nematodes in FT 1 and AT 1 make the data difficult to fit to models. Although we modeled nematodes as presence/absence events and its survival curve was not rejected by our goodness-of-fit test, the occasional isolation of substantial numbers of nematodes from samples collected after more than 1 week of insertion into fresh piles suggests that the samples had somehow been protected. Additional research is needed to consider how to best model enumerable organisms such as nematodes when such outliers are observed. The survival curve approach adequately models the probability that all nematodes are eliminated, but does not represent the number of nematodes that will survive in the case that a colony survives.

In this field study, we assumed that pile temperature was the most significant factor that varied among treatments, but other factors such as moisture, porosity, and compost feedstock may also affect pathogen suppression. Pile temperature itself is a function of moisture, porosity, and feedstock chemistry, however, because each contributes to the microorganism activity that heats the piles. These factors are therefore indirectly represented in the temperature history of each experiment.

Compared with previous studies using controlled environments that demonstrated uniform kill in minutes or hours (12-14,24,31), pathogens were found to be inactivated more slowly in passively managed compost even when the temperatures were above established lethal thresholds. The temperature histories used to determine temperature-adjusted time (TAT) to inactivation in this study were based on calculated averages, which may not explicitly account for cool spots where pathogens may survive for longer time than in laboratory studies, although the large number of replicates included in our study increases the chance that pathogens harbored in cool spots are in fact measured. Furthermore, temperatures were never uniform within compost piles, but rather were warmer at the centers and cooler at the edges, especially in fresh piles. The TAT needed to inactivate pathogens in passively managed compost piles is therefore not the same as the TAT needed in a carefully controlled treatment. Rather, it represents the average TAT that would be measured at a particular pile depth.

Our data suggest that chopped A. mellea from stump or root wood poses little risk of being distributed from green waste stockpiles as viable inoculum. P. cinnamomi escape is possible, however, if the pathogen is introduced into aged stable stockpiles just prior to their use or sale. T. semipenetrans colonies may survive in protected areas of unturned piles but generally, pile temperatures are sufficient for inactivation. Sclerotia-forming pathogens such as $S$. sclerotiorum pose the greatest risk, as temperatures in unturned stockpiles may be uneven or insufficient to kill all propagules of $S$. sclerotiorum within the time examined by this study. To ensure eradication of persistent fungi and protected nematode colonies, green waste stockpiles should be turned intermittently to mix pile contents and move propagules to a part
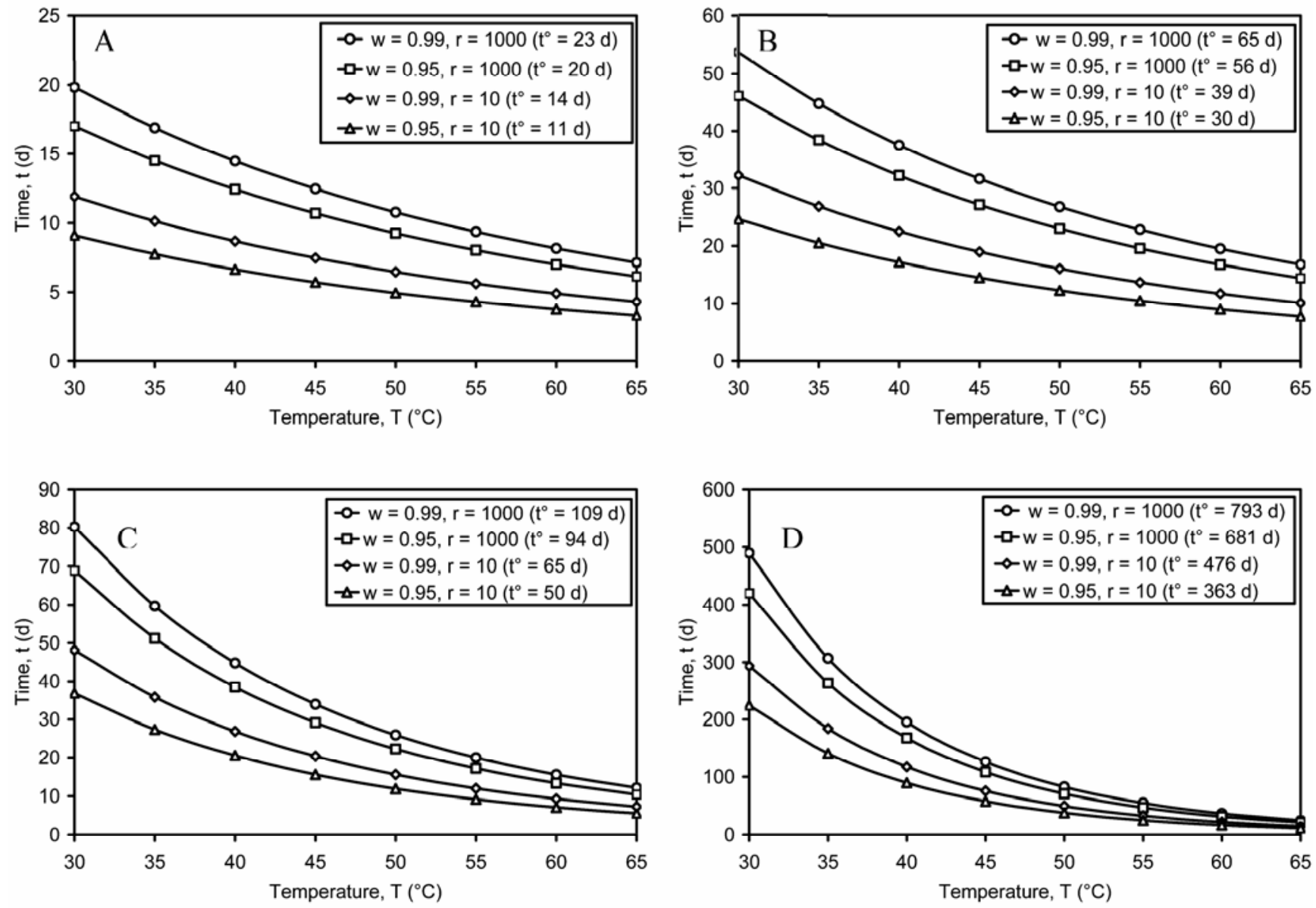

Fig. 2. Time required to completely inactivate 10 and 1,000 A, oak root rot (Armillaria mellea) hyphal mats, B, avocado root rot (Phytophthora cinnamomi) mycelia, $\mathbf{C}$, citrus nematodes (Tylenchulus semipenetrans), and $\mathbf{D}$, lettuce drop (Sclerotinia sclerotiorum) sclerotia as a function of temperature in unturned fresh (recently chipped) and aged (18-month-old) green waste piles to a specified confidence level $(w=0.95$ and 0.99$)$ near Oxnard, CA. Time on the axis is not adjusted for temperature; the equivalent temperature-adjusted time $\left(t^{\circ}\right)$ appears in the legend. Goodness-of-fit was rejected for the $P$. cinammomi model, however, indicating the pile temperature did not relate to P. cinammomi survival; it is included for comparison purposes only. 
of the pile where they are more likely to be killed by heat, microbial attack, or chemical degradation that occurs during active aerobic composting.

\section{ACKNOWLEDGMENTS}

We thank the Hansen Trust for their financial support, Shoreline Organics for the green waste and composting site facilities, M. Yamamoto and J. Rogers for field assistance, E. Pond for lab assistance, and T. Paulitz for editorial review.

\section{LITERATURE CITED}

1. Becker, J. O., Ohr, H. D., Grech, N. M., McGiffen, M. E., Jr., and Sims, J. J. 1998. Evaluations of methyl iodide as a soil fumigant in container and small field plot studies. Pestic. Sci. 52:58-62.

2. Bollen, G. J., Volker, D., and Wijnen, A. P. 1989. Inactivation of soilborne plant pathogens during small-scale composting of crop residues. Netherl. J. Plant Pathol. 95:19-30.

3. Cascadia Consulting Group. 2004. Statewide waste characterization study. California Integrated Waste Management Board, Public Affairs Office, Publications Clearinghouse (MS-6), Sacramento, CA. http://www. ciwmb.ca.gov/Publications/LocalAsst/34004005.pdf

4. Crohn, D. M., Faber, B., Downer, A. J., and Daugovish, O. 2007. Probabilities for survival of glassy-winged sharpshooter and olive fruit fly pests in urban yard waste piles. Biores. Tech. doi:10.1016/j.biortech.2007.01.054

5. Crohn, D. M., Ruud, N. C., Decreynaire, J. G., and Carlon, D. B. 2005. Goodness-of-fit test for modeling tracer breakthrough curves in wetlands. J. Environ. Eng. 131:242-251.

6. Crohn, D. M., and Valenzuela-Solano, C. 2003. Modeling temperature effects on decomposition. J. Environ. Eng. 129:1149-1156.

7. Dittmer, U., Buddle, K., Stindt, A., and Weltzien, H. C. 1990. Der einfluss der kompostierung von kompostsubstraten and wasserigen kompostextraken auf verschiedene pflanzenkrankheitserreger. Gesunde Pflanzen 42:219-233.

8. Downer, A. J., Menge, J. A., and Pond, E. 2001. Association of cellulytic enzyme activities in eucalyptus mulches with biological control of Phytophthora cinnamomi. Phytopathology 91:847-855.

9. Downer, J., Faber, B., and Menge, J. 2002. Factors affecting root rot control in mulched avocado orchards. HortTechnology 12:601-605.

10. Dudoit, S., Shaffer, J. P., and Boldrick, J. C. 2003. Multiple hypothesis testing in microarray experiments. Stat. Sci. 18:71-103.

11. Endo, B. Y. 1962. Lethal time-temperature relations for Heterodera glycines. Phytopathology 52:992-997.

12. Erwin, D. C., and Ribeiro, O. K. 1995. Phytophthora Diseases Worldwide. American Phytopathological Society, St. Paul, MN.

13. Giblin-Davis, R. M., and Verkade, S. D. 1988. Solarization for nematode disinfestation of small volumes of soil. Ann. Appl. Nematol. 2:41-45.

14. Haug, R. T. 1993. Practical Handbook of Compost Engineering. Lewis Publishers, Boca Raton, FL.
15. Heald, C. M., and Robinson, A. F. 1987. Effects of soil solarization on Rotylenchulus reniformis in the lower Rio Grande Valley of Texas. J. Nematol. 19:93-103.

16. Hermann, I., Meissner, S., Bachle, E., Rupp, E., Menke, G., and Grossman, F. 1994. Einflussdes rotenprozesses von bioabfall auf das uberleben von phytopathogenen organismen und von tomatensamen. Z . Pflanzenk. Pflanzen. 101:48-65.

17. Hoitink, H. A. J. 1980. Composted bark, a lightweight growth medium with fungicidal properties. Plant Dis. 64:142-147.

18. Hoitink, H. A. J., and Fahy, P. C. 1986. Basis for the control of soilborne plant pathogens with composts. Annu. Rev. Phytopathol. 24:93-114.

19. Hoitink, H. A. J., Herr, L. J., and Schmitthenner, A. F. 1976. Survival of some plant pathogens during composting of hardwood tree bark. Phytopathology 66:1369-1372.

20. Johnson, N. L., Kemp, A. W., and Kotz, S. 2005. Univariate Discrete Distributions. 3rd ed. John Wiley \& Sons, Hoboken, NJ.

21. Kellam, M. K., and Coffey, M. D. 1985. Quantitative comparison of the resistance to Phytophthora root rot in three avocado rootstocks. Phytopathology 75:230-234.

22. Lemeshow, S., and Hosmer, D. W. 1982. A review of goodness-of-fit statistics for use in the development of logistic regression models. Am. J. Epidemiol. 115:92-116.

23. Miller, F. C. 1991. Biodegradation of solid wastes by composting. Pages 1-31 in: Biological Degradation of Wastes. A. M. Martin, ed. Elsevier Applied Science, London.

24. Miller, F. C., Munnecke, D. M., Wilbur, W., and Darley, E. F. 1976. Effect of heating or drying on Armillaria mellea or Trichoderma viride and the relation to survival of A. mellea in soil. Phytopathology 66:13631368.

25. Noble, R., and Roberts, S. J. 2004. Eradication of plant pathogens and nematodes during composting: A review. Plant Pathol. 53:548-568.

26. Pittenger, D., and Downer, A. J. 2002. The herbicide-contaminated compost issue. Calif. Landscaping Nov.-Dec.:32-34.

27. Raabe, R. D., Weinhold, A., and Wilbur, W. D. 1967. Research on Armillaria mellea-the oak root fungus. Calif. Agric. 21:12-14.

28. Schippers, B., Meijer, J. M., and Liem, J. I. 1982. Effect of ammonia and other soil volatiles on germination and growth of soil fungi. Trans. Br. Mycol. Soc. 79:253-259.

29. Shlevin, E., Saguy, I. S., Mahrer, Y., and Katan, J. 2003. Modeling the survival of two soilborne pathogens under dry structural solarization. Phytopathology 93:1247-1257.

30. Tsao, P. H., and Oster, J. J. 1981. Relation of ammonia and nitrous-acid to suppression of Phytophthora in soils amended with nitrogenous organicsubstances. Phytopathology 71:53-59.

31. Van Loenen, C. A., Turbett, Y., Mullins, C. E., Feilden, N. E. H., Wilson, M. J., Leifert, C., and Seel, W. E. 2003. Low temperature short duration steaming of soil kills soilborne pathogens, nematode pests and weeds. Eur. J. Plant Pathol. 109:993-1002.

32. Walker, J. T. 1962. The sensitivity of larvae and eggs of Meloidogyne species to hot-water treatments. Nematologica 7:19-24.

33. Yuen, G., and Raabe, R. D. 1984. Effects of small-scale aerobic composting on survival of some fungal plant pathogens. Plant Dis. 68:134-136. 